\section{'Carolina Broadleaf' Mustard Green (Brassica juncea) Resistant to the Bacterial Leaf Blight Pathogen Pseudomonas cannabina pv. alisalensis}

\author{
W. Patrick Wechter ${ }^{1,2}$ and Melanie M. McMillan
}

U.S. Department of Agriculture, Agricultural Research Service, U.S. Vegetable Laboratory, 2700 Savannah Highway, Charleston, SC 29414

Anthony P. Keinath

Clemson University, Coastal Research and Education Center, 2700 Savannah Highway, Charleston, SC 29414

\section{J. Powell Smith}

Clemson University Cooperative Extension Service, 605 West Main Street, Suite 109, Lexington, SC 29072

\section{Mark W. Farnham}

U.S. Department of Agriculture, Agricultural Research Service, U.S. Vegetable Laboratory, 2700 Savannah Highway, Charleston, SC 29414

Additional index words. Brassica juncea, leafy-green, open pollinated, host plant resistance
A leafy-green mustard (Brassica juncea L.) cultivar designated Carolina Broadleaf has been released by the Agricultural Research Service of the U.S. Department of Agriculture in 2015. This released cultivar is a narrow genetic-based population of leafy-green mustard derived from a U.S. PI (PI G30988) maintained by the USDA National Plant Germplasm System (NPGS). 'Carolina Broadleaf' is a highly uniform mustard in a similar class as the popular cultivar Florida Broadleaf. However, 'Carolina Broadleaf' has been selected to exhibit high levels of resistance to a bacterial leaf blight disease caused by Pseudomonas cannabina pv. alisalensis (Pca).

Leafy-green mustards are one type of Brassica "leafy greens" among several other important leafy vegetables, including turnip greens (Brassica rapa L.) and collards and kale (both Brassica oleracea var. acephala). More than 28 million $\mathrm{kg}$ of these greens are produced in the United States annually (USDA/NAAS, 2004). Because these crops are grown for the utilization of the foliar portion of the plant, even slight deformity or blemishes of the leaves can result in market rejection and loss of product sales. South Carolina is one of the largest producer of Brassica leafy greens, and average yields for turnip and mustard greens during the summer season have fallen from about 283 boxes/ha to 50 to 58 boxes/ha ( 1 box $=9 \mathrm{~kg}$ ) largely due to a leaf blight that emerged in the early

Received for publication 30 Sept. 2015. Accepted for publication 23 Dec. 2015.

${ }^{1}$ Research plant pathologist.

${ }^{2}$ Corresponding author. E-mail: pat.wechter@ars. usda.gov. relatively new pathogen $P c a$ has been causing a particularly damaging blight of Brassica leaves. Bacterial blight caused by $\mathrm{Pca}$ has now become a significant problem in many Brassica growing areas of the United States, but economic losses for numerous producers in the southeastern United States have been especially severe. $P c a$ has now been reported on numerous crops in most of the leafy greens growing states (Bull et al., 2004a, 2004b; Bull and du Toit, 2009; Koike et al., 2006, 2007; Wechter et al., 2010). Pesticides are not effective against this bacterial disease, and copper has been reported to increase disease incidence (Keinath et al., 2007). Up until now, no commercial mustard green cultivars with significant resistance to $P c a$ have been identified.

'Carolina Broadleaf' is the first mustard green cultivar with high levels of resistance to $P c a$. This cultivar was developed as a possible alternative to the cultivar Florida Broadleaf in areas where $P c a$ is a problem. 'Carolina Broadleaf' has been grown and tested by several leafy greens growers and been deemed acceptable for fresh, chopped prepackages, flash frozen, and canned markets.

\section{Origin}

2000s. In 2001, the combined value of turnip and mustard greens produced in South Carolina was \$7.1 million. The only formal report (Smith and Keinath, 2005) of economic losses in South Carolina were estimated at up to $\$ 1.7$ million per year, or $24 \%$ of the value of these two crops at that time.

Several bacterial pathogens cause leaf spot and blight diseases of Brassica. The
Wechter et al. (2007) evaluated $175 B$ juncea PIs from the North Central Regional Plant Introduction Station at Ames, IA, and 51 B. juncea PIs from the Northeast Regional PI Station (NRPIS) at Geneva, NY, for response to inoculation by $P c a$. Only one $B$. juncea PI (G30988) from NRPIS was confirmed to be highly resistance to $P c a$ after undergoing repeated tests. Most plants of this

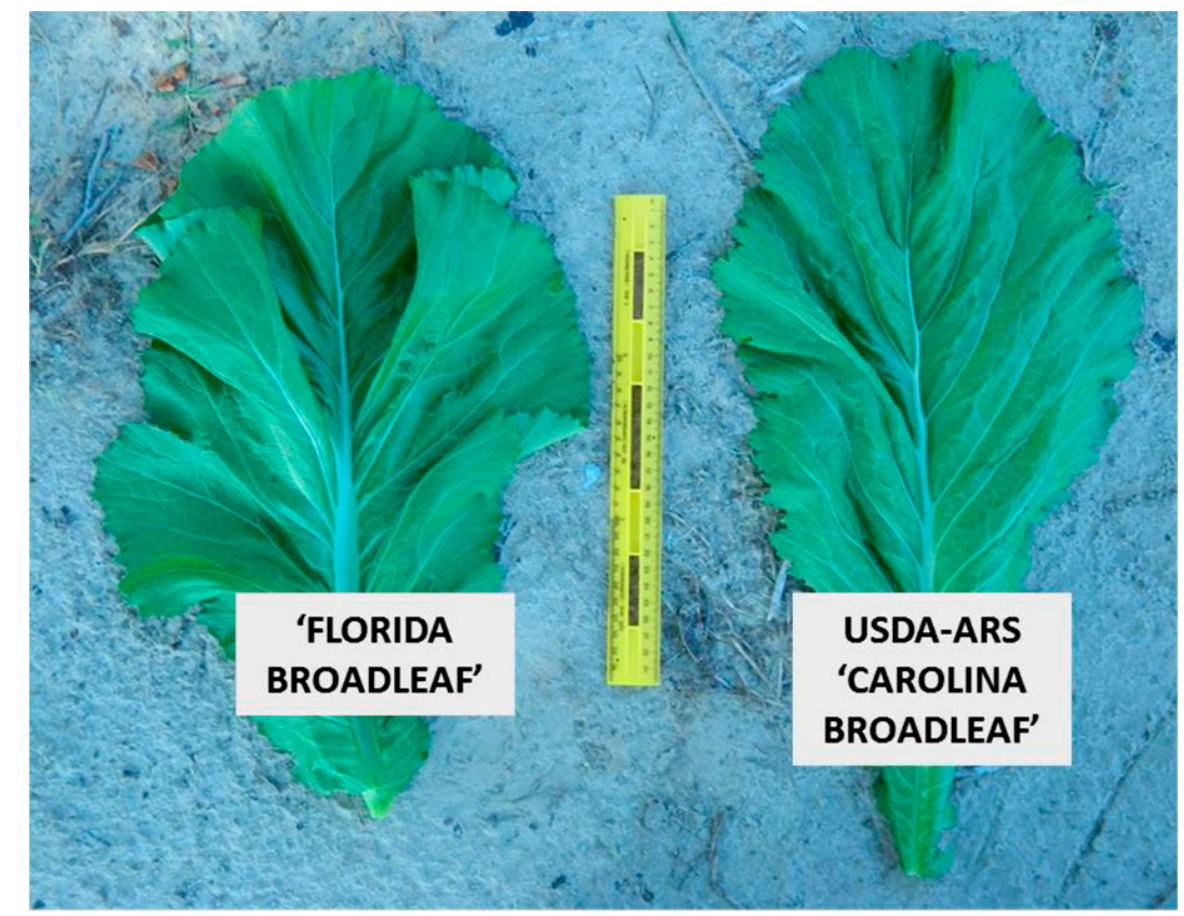

Fig. 1. Typical leaf phenotypes for the standard cultivar Florida Broadleaf and the new USDA-ARSrelease 'Carolina Broadleaf'. 


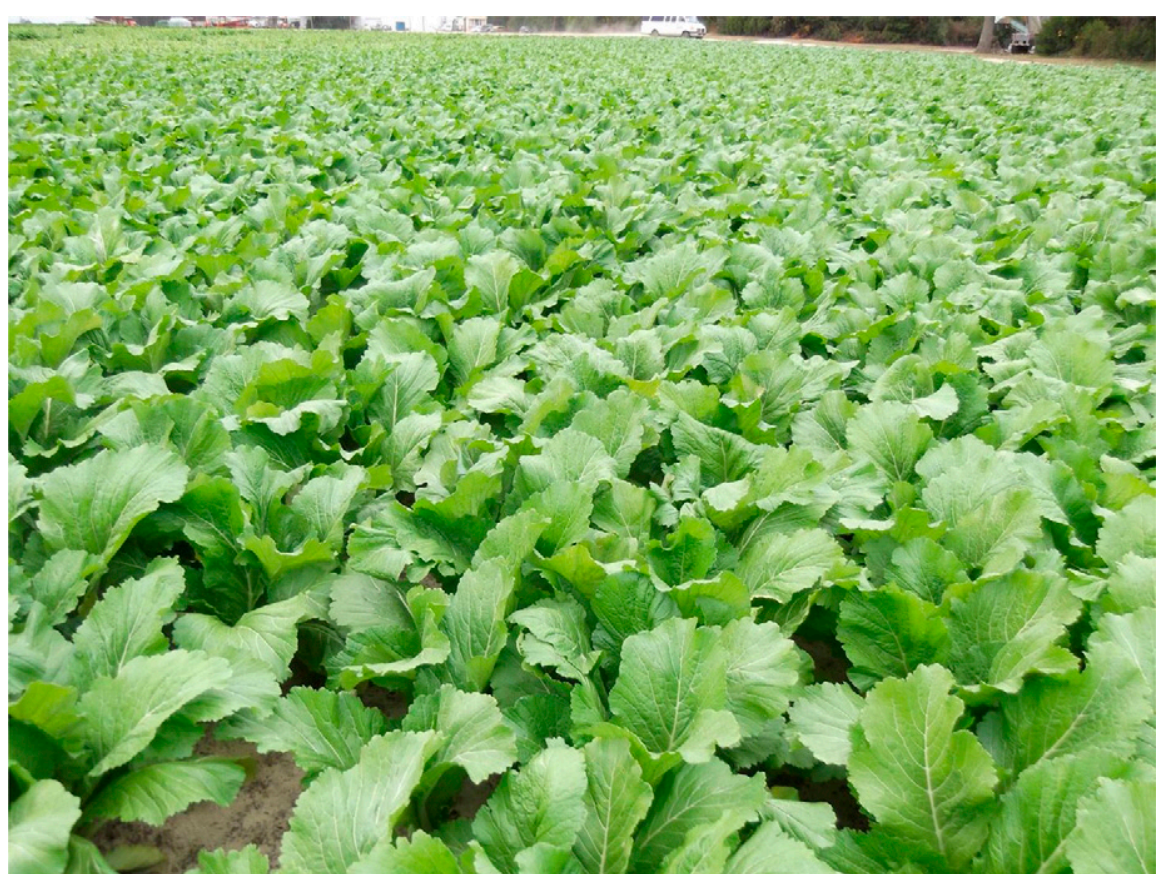

Fig. 2. Uniformity of stand in a large field trial of 'Carolina Broadleaf' in Lexington, SC, in the summer of 2014.

Table 1. Mean fresh weight of harvested leaves per plant cut above a 16-cm height from the ground surface for 'Carolina Broadleaf' and three standard mustard green cultivars (Florida Broadleaf, Southern Curled Giant, and Tendergreen) grown in field trials conducted at Charleston, SC, in Spring and Summer 2015 using growing conditions previously described (Wechter et al., 2013). ${ }^{2}$

\begin{tabular}{lcc}
\hline Cultivars & Leaf wt Apr./May 2015 $(\mathrm{g} / \mathrm{plant})$ & Leaf wt June/July 2015 \\
\hline Carolina Broadleaf & $138.65 \mathrm{a}^{\mathrm{w}}$ & $167.83 \mathrm{~b}$ \\
Florida Broadleaf & $131.05 \mathrm{~b}$ & $217.35 \mathrm{ab}$ \\
Southern Giant Curl & $108.83 \mathrm{~b}$ & $176.85 \mathrm{~b}$ \\
Tendergreen & $145.93 \mathrm{c}$ & $252.30 \mathrm{a}$ \\
\hline
\end{tabular}

${ }^{\mathrm{z}}$ Spring and summer trials were conducted separately and both involved a randomized complete block design with four replications. Individual plots were $12 \mathrm{~m}$ in length and all plants were harvested from a $2.5 \mathrm{~m}$ length of bed with number of plants and total weight of leaves recorded.

y The spring trial was planted 9 Apr. and harvested on 14 May.

xThe summer trail was planted 29 June and harvested 31 July.

${ }^{w}$ Means followed by different letters are significantly different from one another based on a protected least significant difference $(P \leq 0.05)$ determined by analysis of variance.

Table 2. Mean percentage of diseased leaf tissue of seedlings inoculated with Pseudomonas cannabina pv. alisalensis rated 10 days postinoculation. Tests 1 and 2 were independent tests conducted in the greenhouse using a randomized complete block design with eight replications. Plant growth conditions and inoculation techniques were conducted as described by Wechter et al. (2013).

\begin{tabular}{lcc}
\hline & \multicolumn{1}{c}{ Test 1 } & Test 2 \\
\cline { 2 - 3 } Cultivars & \multicolumn{2}{c}{ Diseased leaf tissue (\%) } \\
\hline Carolina Broadleaf & $0.28 \mathrm{a}^{\mathrm{z}}$ & $1.53 \mathrm{a}$ \\
Florida Broadleaf & $6.55 \mathrm{~b}$ & $12.55 \mathrm{~b}$ \\
Southern Giant Curl & $4.15 \mathrm{~b}$ & $28.80 \mathrm{c}$ \\
Tendergreen & $28.03 \mathrm{c}$ & $49.00 \mathrm{~d}$ \\
\hline
\end{tabular}

${ }^{\mathrm{z}}$ Means followed by different letters are significantly different from one another based on a protected least significant difference $(P \leq 0.05)$ determined by analysis of variance.

PI exhibited resistance; however, some variation in response to the disease was observed, the PI was not uniform for leaf phenotype, and significant off-types among plants were observed. Highly resistant individuals of G30988 were selected in Fall 2006, grown in a pot, left outdoors at the U.S. Vegetable Laboratory, Charleston, SC to effectively vernalize them, moved to a greenhouse in late winter at flower onset, and then self-pollinated by hand to produce seed. Progeny of these plants were tested for disease response in 2007, and a single plant from a uniformly resistant family was selected, vernalized, and self-pollinated as in the previous winter. An additional round of progeny testing, single-plant selection, and self-pollinations were repeated in 2008. During these selection cycles, plants were selected on best resistance, and not to leaf phenotype. Progeny tests in 2009 indicated all progeny were uniformly resistant, as well as uniform for plant phenotype. In Fall 2009, 25 plants were grown in pots outdoors through the winter, allowed to vernalize, moved to a $6^{\prime} \times$ $6^{\prime} \times 6^{\prime}$ cage as they began to flower, and then allowed to intercross with the assistance of pollinating flies. Seed harvested from this cage was deemed breeder seed of
'Carolina Broadleaf'. This variety is a narrow genetic base population (e.g., $\mathrm{S}_{3}$ derived) and is highly uniform for plant morphology and resistance to Pca. It can easily be increased by growing plants in a cage with insect pollinators or in an isolated field plot where native pollinators are active. Although pollinators will increase seed set, 'Carolina Broadleaf' exhibits a high degree of self-compatibility and plants will readily set seed even in the absence of pollinators.

\section{Description and Performance}

'Carolina Broadleaf' is a large mustard green with long, wide leaves. It is similar in size to the cultivar Florida Broadleaf when grown under standard cultural conditions (Fig. 1). Mature leaves of 'Carolina Broadleaf' have an average length of $53( \pm 4) \mathrm{cm}$ and a mean width of $28( \pm 2) \mathrm{cm}$ (Fig. 1). Leaves are serrated along the margins and have a characteristic pungent "mustard" taste. The color of 'Carolina Broadleaf' foliage is also similar to that of 'Florida Broadleaf'; the mean $\mathrm{L}-\mathrm{a}-\mathrm{b}$ color score for 'Carolina Broadleaf' is $\mathrm{L}=47.00, \mathrm{a}=-17.27$, and $\mathrm{b}=27.59$ and for 'Florida Broadleaf' is $\mathrm{L}=46.37, \mathrm{a}=-16.50$, and $b=26.41$. 'Carolina Broadleaf' has been tested in large, on-farm plantings in South Carolina, and leaf quality has been deemed acceptable for fresh or processing markets (Fig. 2). Yields in these tests have been deemed comparable to those for 'Florida Broadleaf'. Small replicated tests in the field at Charleston confirm those findings (Table 1). Like most mustards, 'Carolina Broadleaf' requires a cold treatment or vernalization to end vegetative growth and stimulate flowering; however, the cold requirement for this mustard may be less than for other mustard cultivars [e.g., Southern Curled Giant (B. juncea L.)] and it has a tendency to bolt quickly during winter or early spring productions when there are prolonged cold periods. This tendency makes 'Carolina Broadleaf' best adapted to late spring through fall environments.

'Carolina Broadleaf' is not immune to $P c a$, but it exhibits high levels of resistance to this pathogen in greenhouse and field studies (Wechter et al., 2013). When leaves of 'Carolina Broadleaf' are exposed to the pathogen they exhibit no discernable disease, or few lesions which manifests as $<0.5-\mathrm{mm}$ necrotic flecks that are visible on less than $2 \%$ of the plant (Table 2 ). These leaves are considered "marketable" by major mustard green growers and processors. When $\mathrm{Pca}$ infects other commonly grown mustard green cultivars like Florida Broadleaf, Southern Curled Giant, and Tendergreen (Brassica periviridis L.), infection leads to expanding and coalescing lesions that can result in complete loss of foliar tissue. Expansion of lesions in 'Carolina Broadleaf' is not observed postinoculation in the greenhouse or the field. In inoculated field trials in 2010 and 2011, 'Carolina Broadleaf' foliage was essentially free of bacterial leaf blight symptoms, whereas 'Florida Broadleaf' and 'Tendergreen' foliage were severely damaged 
by the disease (Wechter et al., 2013). The mean healthy leaf weight of 'Carolina Broadleaf' in those two trials was four times greater than the healthy leaf weight for 'Tendergreen', and $50 \%$ greater than the healthy weight for 'Florida Broadleaf'. Evidence indicates that the resistance to $P c a$ exhibited by 'Carolina Broadleaf' is controlled by more than one gene (Wechter et al., 2013).

\section{Availability}

Small quantities of seed of 'Carolina Broadleaf' are available for distribution to interested research personnel and plant breeders who make written request to Dr. Patrick Wechter, U.S. Vegetable Laboratory, 2700 Savannah Highway, Charleston, SC 29414-5334 (Pat.Wechter@ars.usda.gov). Seed of 'Carolina Broadleaf' will also be submitted to the NPGS, where it will be available for research and breeding. It is requested that appropriate recognition of the source be given when this germplasm contributes to research or development of a new breeding line or cultivar.

\section{Literature Cited}

Bull, C.T. and L.J. du Toit. 2009. First report of bacterial blight on conventionally and organically grown arugula in Nevada caused by Pseudomonas syringae pv. alisalensis. Plant Dis. 93:109.

Bull, C.T., P.H. Goldman, and S.T. Koike. 2004a Bacterial blight on arugula, a new disease caused by Pseudomonas syringae pv. alisalensis in California. Plant Dis. 88:1384.

Bull, C.T., P.H. Goldman, N.C. Morris, S.T. Koike, and D.Y. Kobayashi. 2004b. Expanded host and geographic range of Pseudomonas syringae pv. alisalensis. Phytopathology 94:S12.

Keinath, A.P., V.B. DuBose, W.H. May, III, and W.P. Wechter. 2007. Evaluation of Actigard and Kocide to manage bacterial leaf spots on turnip greens, 2006. Plant Dis. Mgt. Rpt. 1: V103.

Koike, S.T., K. Kammeijer, C.T. Bull, and R.D. O'Brien. 2006. First report of bacterial blight of romanesco cauliflower (Brassica oleracea var. botrytis) caused by Pseudomonas syringae pv. alisalensis in California. Plant Dis. 90:1551.

Koike, S.T., K. Kammeijer, C.T. Bull, and R.D. O'Brien. 2007. First report of bacterial blight of rutabaga (Brassica napus var. napobrassica) caused by Pseudomonas syringae pv. alisalensis in California. Plant Dis. 91:112.

Smith, J.P. and A.P. Keinath. 2005. Crop profile for leafy greens and collards (Fresh Market) in South Carolina. USDA Southern Region Pest Management Center. 21 July 2016. <https:// ipmdata.ipmcenters.org/documents/cropprofiles/ SCleafygreens.pdf $>$.

United States Department of Agriculture, National Agricultural Statistics Service (USDA/NAAS). 2004. Vegetable summary. USDA/NAAS, Washington, DC.

Wechter, W.P., M.W. Farnham, J.P. Smith, and A.P. Keinath. 2007. Identification of resistance to peppery leaf spot among Brassica juncea and Brassica rapa Plant Introductions. HortScience 42:1140-1143.

Wechter, W.P., A.P. Keinath, M.W. Farnham, and J.P. Smith. 2010. First report of bacterial leaf blight on broccoli and cabbage caused by Pseudomonas syringae pv. alisalensis in South Carolina. Plant Dis. 94:132.

Wechter, W.P., A.P. Keinath, M.L. McMillan, P. Smith, and M.W. Farnham. 2013. Expression of leaf blight resistance in Brassica leafy greens under field conditions and inheritance of resistance in a Brassica juncea source. Plant Dis. 97:131-137. 